\title{
Effect of Electrical Injection of Corrosion Inhibitor on the Corrosion of Steel Rebar in Chloride-Contaminated Repair Mortar
}

\author{
The Huyen Nguyen, ${ }^{1}$ Tuan Anh Nguyen, ${ }^{2}$ Thien Vuong Nguyen, ${ }^{2}$ Van Khu Le, ${ }^{1}$ \\ Thi Mai Thanh Dinh, ${ }^{2}$ Hoang Thai, ${ }^{2}$ and Xianming Shi ${ }^{3}$ \\ ${ }^{1}$ Department of Chemistry, Hanoi National University of Education, 136 Xuan Thuy, Cau Giay, Hanoi 122000, Vietnam \\ ${ }^{2}$ Institute for Tropical Technology, 18 Hoang Quoc Viet, Cau Giay, Hanoi 122300, Vietnam \\ ${ }^{3}$ Department of Civil and Environmental Engineering, Washington State University, Pullman, WA 99164-2910, USA
}

Correspondence should be addressed to Tuan Anh Nguyen; ntanh2001@yahoo.com

Received 16 September 2015; Revised 23 October 2015; Accepted 1 November 2015

Academic Editor: Yu Zuo

Copyright ( $) 2015$ The Huyen Nguyen et al. This is an open access article distributed under the Creative Commons Attribution License, which permits unrestricted use, distribution, and reproduction in any medium, provided the original work is properly cited.

\begin{abstract}
The electrical rehabilitation treatments of repair mortar were performed with tetrabutylammonium bromide salt (TBAB) at an electrical current density of $5 \mathrm{~A} / \mathrm{m}^{2}$, using two electrolytes $\left(0.1 \mathrm{M} \mathrm{NaOH}\right.$ and $0.1 \mathrm{M} \mathrm{Na}_{3} \mathrm{BO}_{3}$ solutions), and for two time periods ( 1 and 4 weeks), respectively. The average organic cation-based inhibitor's concentration in cement mortars before and after this treatment was quantified using the UV-Vis spectroscopy. The experimental results reveal that the EICI treatment with $0.1 \mathrm{M} \mathrm{Na}_{3} \mathrm{BO}_{3}$ was more effective in injecting the inhibitor and in improving the chloride penetration resistance and compressive strength of the mortar, relative to using $0.1 \mathrm{M} \mathrm{NaOH}$ as electrolyte. In this case, after the 4-week EICI treatment, [TBA ${ }^{+}$contents were 2.3 $\%$ and $2.4 \%$ by mass of cement mortar for uncontaminated and salt-contaminated mortars, respectively. After the 4 -week EICI treatment, the apparent diffusion coefficients of chloride anion in cement mortar were decreased by $40 \%$ from $1.52 \times 10^{-10} \mathrm{~m}^{2} / \mathrm{s}$. The EICI treatment was able to halt the chloride-induced corrosion of the steel rebar by promoting its passivation. The 2-week EICI treatment using sodium hydroxide and sodium borate solutions decreased the corrosion current density of the rebar by $77.8 \%$ and $78.5 \%$, respectively, approximately two months after the treatment.
\end{abstract}

\section{Introduction}

For reinforced concrete structures such as highway bridges, the chloride-induced corrosion of rebar has been a major problem with serious economic and safety implications [1]. Chloride, often originated from marine environments [2] or deicing applications [3], can initiate the rebar corrosion once its concentration exceeds a threshold level. The threshold chloride contents in published literature are scattered over a wide range of values, attributable to the variability in measurement methods and the numerous factors that affect steel corrosion in concrete, such as the $\mathrm{pH}$ of concrete pore solution, the electrochemical potential of the steel, and the physical condition of the steel/concrete interface [46]. In normal circumstances, the threshold chloride content typically varies from $0.2 \%$ to $0.5 \%$ by weight of cement $[7,8]$.

The durability and serviceability of concrete (or mortar) and the embedded rebar can be improved by limiting the amount of undesirable species or incorporating the amount of beneficial species in concrete [9-11]. However, species dissipation relying solely on natural diffusion is too slow to be effective or practical. Furthermore, the concentration of an ionic species can no longer be reduced via diffusion once a threshold level is reached, due to such mechanisms as species binding. As such, engineers have developed various approaches to enforce the transport of species under applied physical fields.

Among the methods to preserve or rehabilitate reinforced concrete structures, corrosion inhibitors are the most 
versatile due to the possibility of application at any time along the service life of the structure. Corrosion inhibitors can be added to the fresh concrete, dissolved into the water used for mixing [10, 12-14], or can be applied on the surface of the hardened concrete [11, 14-16]. In the latter case, the solution containing the inhibitor has to penetrate through the microstructure of hardened concrete towards the rebar.

Electrical injection of corrosion inhibitor (EICI) emerged recently as a promising solution to rebar corrosion in concrete structures [17-23]. Pan et al. [18] conducted a laboratory investigation to identify available organic cation-based inhibitors for EICI and a subsequent numerical investigation to examine the effect of various factors (inhibitor type, external current density, and treatment time) on the efficiency of EICI into concrete. Liu and Shi [19] presented a comprehensive review on the state of the knowledge about EICI, which covered both laboratory and numerical studies. Kubo et al. [21] reported "a site trial of (EICI) applied to a 40year-old carbonated high-speed railway viaduct in Tokyo." Sánchez and Alonso [20] reported that the injection of nitrite (an anion-based inhibitor) was facilitated by using a nontraditional configuration featuring an external cathode (instead of anode) to the rebar.

As an organic corrosion inhibitor, tetrabutylammonium bromide (TBAB) is expected to mitigate the corrosion of steel by forming an adsorbed film onto the metallic substrate and thus acting as a barrier to limit the access of chloride and oxygen to the steel surface. In other words, it is a cathodic inhibitor $[24,25]$. A $\left[\mathrm{TBA}^{+}\right]$concentration as low as $5 \mathrm{mM}$ on steel can effectively inhibit the corrosion of steel in a typical chloride-contaminated mortar (pore solution of $\mathrm{pH} 13$ with $3.0 \mathrm{wt} . \% \mathrm{NaCl}$ ) [18]. The inhibition function of $\left[\mathrm{TBA}^{+}\right]$generally increases with its concentration, and a concentration above $10 \mathrm{mM}$ can be expected to form a reliable protective film on the steel surface. The apparent diffusion coefficient $D$ of $\left[\mathrm{TBA}^{+}\right]$ions in an ordinary Portland cement mortar was reported by Pan et al. [18] to be $1.2 \times 10^{-11} \mathrm{~m}^{2} / \mathrm{s}$. By using the two-dimensional finite element model, the concentration evolution of the TBAB inhibitor and chloride were predicted in concrete. To reach a $54 \mathrm{mM}\left[\mathrm{TBA}^{+}\right]$concentration at the critical location on steel rebar embedded in 2-inch thick concrete, the treatment time (under an electric field of $5 \mathrm{~A} / \mathrm{m}^{2}$ in $\mathrm{NaOH}$ electrolyte) would be 16 weeks.

Repair mortar is commonly used to rehabilitate reinforced concrete structures or components that exhibit a relatively high level of distress. The mortar is often applied to the bridge or building structure once the damaged concrete is removed and corroded rebar is cleaned [9, 26, 27]. While the application of EICI treatment has been proven effective in enforcing corrosion inhibitors into preexisting concrete structure, little knowledge is available in the published domain regarding its effect on the property of repair mortar or on the corrosion of the embedded steel. Research is also needed in identifying an effective external electrolyte for reducing the treatment time. In this context, this work aims to address such knowledge gaps and shed more light on this promising technology of electrochemical rehabilitation.

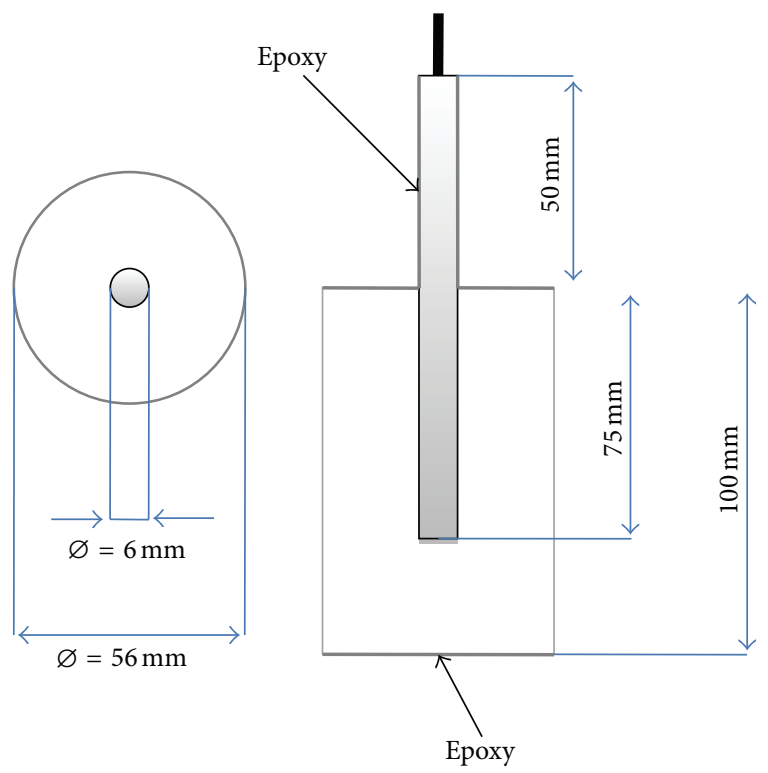

FIGURE 1: Diagram of the steel reinforced mortar samples: cover thickness $=25 \mathrm{~mm}$; steel bar diameter $=6 \mathrm{~mm}$.

\section{Materials and Methods}

2.1. Materials. Tetrabutylammonium bromide was obtained from Sigma Aldrich (USA). The cement mortars used ASTM Type I Portland Cement (Vietnam Portland PC30) [28]. The fine aggregate used was river sand sieved to allow a maximum aggregate size of $2 \mathrm{~mm}$ before water-saturating, proportioning, and admixing. The steel rebar, purchased from Vietnam Hoa Phat Steel Co. Ltd. (Hung Yen, Vietnam), was low carbon steel wire rod (diameter of $6.0 \mathrm{~mm}$, JIS G35051996, SWRM6), with the following chemical composition: C ( $\leq 0.08 \%), \mathrm{Mn}(\leq 0.6 \%), \mathrm{P}(\leq 0.045 \%)$, and S $(\leq 0.045 \%)$.

Steel rebar was embedded in cement mortar, with a mor$\operatorname{tar}$ cover of $25 \mathrm{~mm}$ (Figure 1). To simulate salt-contaminated repair mortar, the cement mortar was made with the weight ratio of cement:sand: water:sodium chloride of $1: 1.75: 0.45: 0.005$. Some mortars were made without any sodium chloride added, to simulate uncontaminated repair mortar. Note that the thickness of repair mortar is assumed to be $25 \mathrm{~mm}\left(1^{\prime \prime}\right)$ in this case, while in practice the repair mortar could be up to 3 inches thick. The repair mortar in this work features a water/cement ratio $(\mathrm{w} / \mathrm{c})$ of 0.45 , while in practice the repair mortar could feature a w/c of 0.4 or lower.

After mixing, the fresh mixture was poured into polypropylene plastic molds to form $\Phi 100 \mathrm{~mm} \times 50 \mathrm{~mm}$ cylindrical samples. The sample without added sodium chloride was also fabricated. The steel reinforced cement mortar specimens were demolded after $24 \mathrm{~h}$ and then cured in a wet chamber (relative humidity in excess of $95 \%$, temperature of $25^{\circ} \mathrm{C}$ ) for 28 days, before being subjected to the electrochemical tests.

2.2. EICI Experimental Setup. The EICI treatment was performed by using a constant current with $0.1 \mathrm{M} \mathrm{NaOH}$ or $0.1 \mathrm{M}$ $\mathrm{Na}_{3} \mathrm{BO}_{3}$ solutions containing $25 \mathrm{mM}$ TBAB as the electrolyte 


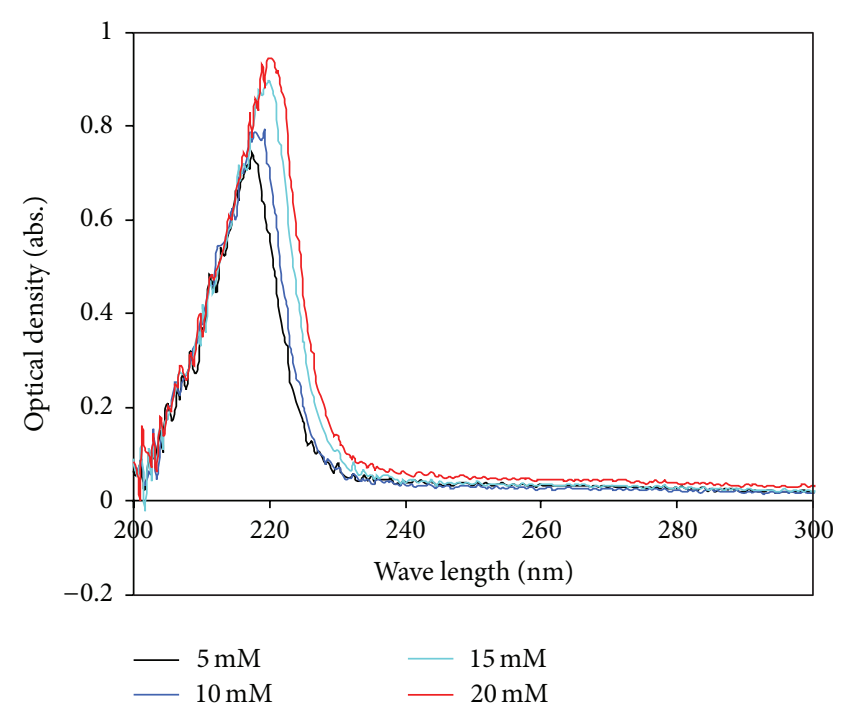

(a)

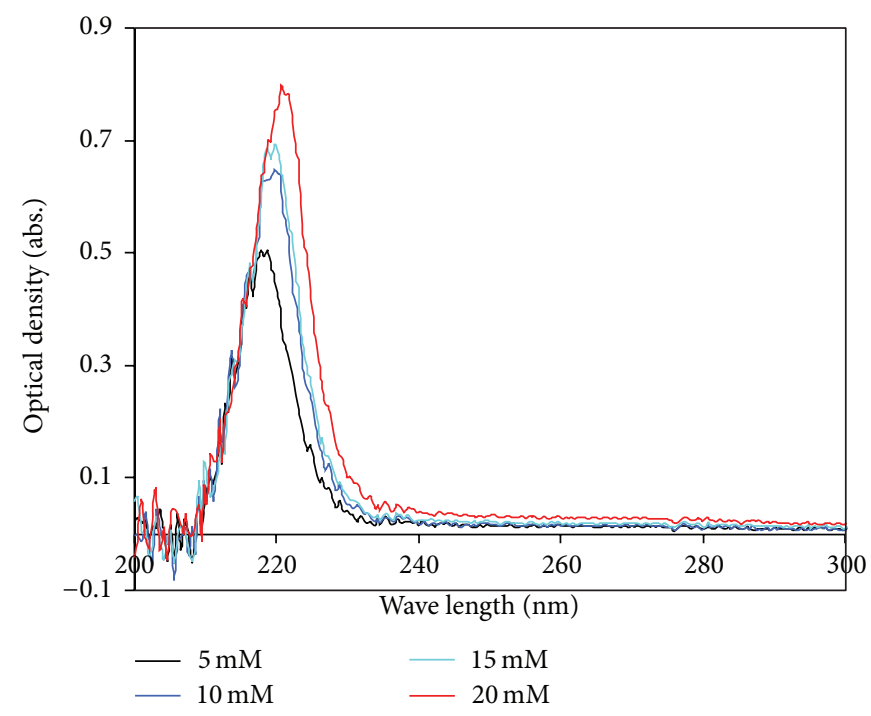

(b)

FIGURE 2: UV-visible spectra of four standard TBAB solutions: (a) in pH 7 aqueous solutions; (b) in pH 11 aqueous solutions.

and stainless-steel 304 mesh as the external anode. The solution was replaced every 2 to 3 days to maintain alkalinity.

For duplication of each test, 10 steel reinforced mortars were connected in series. Each steel rod contained inside the mortar was connected to a negative terminal of a power supply so that the steel reinforcement acted as a cathode. At the same time, the stainless-steel mesh was connected to the positive terminal of the power supply, which acted as the anode. The electrical current density delivered on the steel rod surface was controlled at $5 \mathrm{~A} / \mathrm{m}^{2}$. This treatment lasted one to four weeks, based on the experimental design.

2.3. Quantifying Inhibitor Concentration in Cement Mortars. The ultraviolet- (UV-) visible absorbance spectroscopy is a proven technology for accurately detecting organic chemicals in aqueous solutions $[29,30]$. In this study, Spectroscopy CINTRA 40 (USA) was used.

At the end of the EICI treatment (after one or four weeks), the mortar specimens were cut into slices and later powdered. The powder was then screened through a $300 \mu \mathrm{m}$ sieve, ovendried at $80^{\circ} \mathrm{C}$ overnight, and cooled to room temperature. Five grams of dry mortar powder was added to $50 \mathrm{~mL}$ of the distilled water solution and then sonicated for 1 hour before the solution was subjected to UV-Vis spectroscopy. The $\mathrm{pH}$ of this solution was about 11.

By testing four standard alkaline aqueous solutions $(\mathrm{pH}$ 11) of TBAB ( $5 \mathrm{mM}$ to $20 \mathrm{mM}$ ), a calibration curve was established to correlate the optical density at the characteristic peak (Figure 2) and the inhibitor concentration. The calibration curve was then used to determine the TBAB concentration in cement mortar samples after EICI treatments. As shown in Figure 3, the calibration curves established with these standard solutions of $1 \mathrm{mM} \mathrm{NaOH}(\mathrm{pH}$ 11) showed a strong linear correlation between the natural logarithm of

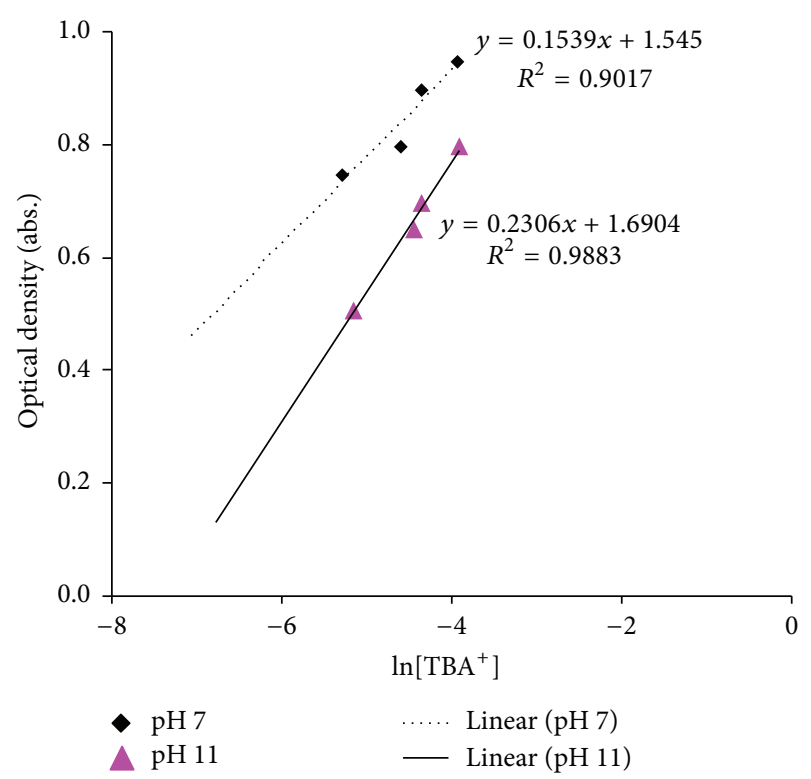

FIGURE 3: Calibration curve in aqueous TBAB solutions at $\mathrm{pH} 7$ and pH 11.

the TBAB concentration and optical density (with high $R$ square value).

\subsection{Electrochemical Characterization of Rebar in Cement Mor-} tar. Approximately 2 months after the EICI treatment ended, the electrochemical response of the rebar was measured to evaluate the effectiveness of the treatment and the ability of the rebar to be repassivated. The untreated mortar specimens were used as controls. Electrochemical measurements were conducted using a three-electrode system. The steel rebar 
in the cement mortar served as the working electrode, while the counter electrode and the reference electrode used were a platinum mesh and a saturated calomel electrode (SCE), respectively. To resolve the effect of the EICI test on the corrosion of steel rebar, the potentiodynamic weak polarization method was employed.

In the potentiodynamic weak polarization test, the steel was polarized around its open circuit potential $(-30 \mathrm{mV}$ to $30 \mathrm{mV}$ versus OCP) by a direct current (DC) signal at a scan rate of $0.2 \mathrm{mV} / \mathrm{s}$. Polarization resistance $\left(R_{p}\right)$ is defined by the slope of the potential current density plot at the corrosion potential. Corrosion current density $\left(i_{\text {corr }}\right)$ is calculated from $i_{\text {corr }}=B / R_{p}$, assuming $B=26 \mathrm{mV}$ or $B=52 \mathrm{mV}$, depending on the active or passive state of the rebar. Corrosion activity of rebar could be defined simply by using its OCP value following ASTM C 876 Standard (when the OCP > -0.125 , the probability of no corrosion $>90 \%$ ).

2.5. Testing Compressive Strength of Cement Mortar. The compressive strength test was carried out by breaking cylindrical mortar specimens $(56 \mathrm{~mm}$ in diameter and $56 \mathrm{~mm}$ in length) in a hydraulic universal testing machine (Model WE$1000 \mathrm{~B}$, Jinhua Jinshi) using a loading rate of $0.6 \mathrm{MPa} / \mathrm{s}$ with the load and displacement data were automatically recorded. The mortar cylinders had the rebar inside, which was cut off at the end. The cylinders were each surface-ground and then the ends were polished with fine silicon carbide paper to ensure a uniform surface finish (and thus a uniformly distributed load) before being subjected to the compressive strength test. The ultimate compressive strength then was calculated by dividing the load at failure by the cross-sectional area resisting the load. The untreated specimens, also cured for 28 days after casting, were subjected to the identical procedure. The test results are the average of specimens made from the same batch mixture.

2.6. Electromigration Test. To test the chloride permeability of cement mortars, electromigration experiments were performed using the two half-cells as shown in Figure 4.

The polypropylene plastic cells feature a disc-shaped mortar specimen that separates the chloride anion source $(3 \% \mathrm{NaCl})$ and the destination solution $\left(4.3 \% \mathrm{NaNO}_{3}\right)$. The $\sim 20 \mathrm{~mm}$ thick mortars discs were cut from the center of either EICI-treated mortars or the untreated control mortar (uncontaminated sample). The exposed rebar surfaces were sealed using an epoxy resin. Each of the two half-cells contained one platinum electrode with an exposed surface area of $1 \mathrm{~cm}^{2}$. Once the mortar disc, electrolytes, and electrodes were in place, a 20 -volt DC electric field was maintained across the disc through the two platinum electrodes in the two compartments. During the test, readings of open circuit potential (OCP) of the calibrated $\mathrm{Ag} / \mathrm{AgCl}$ chloride sensor in the destination solution were taken periodically, using a mercury/mercurous sulfate electrode as the reference electrode.

The $\mathrm{Ag} / \mathrm{AgCl}$ sensor was used to monitor the evolution of free chloride anion $\left(\mathrm{Cl}^{-}\right)$concentration in the destination solution, as its OCP data was compared against a standard

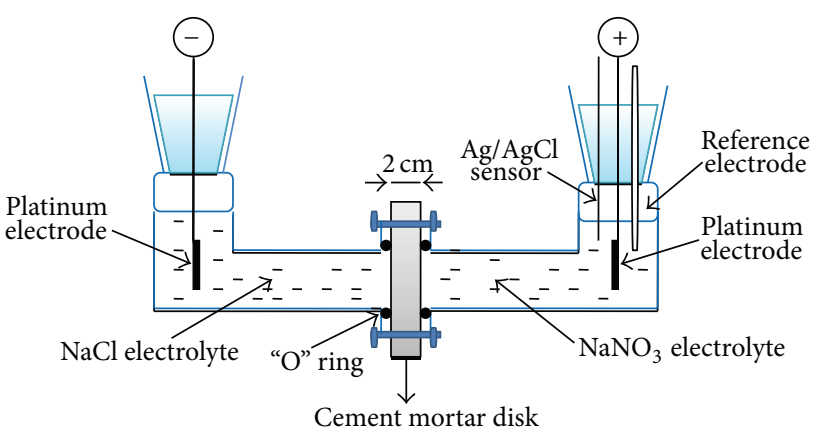

FIGURE 4: Experimental setup for electromigration tests.

calibration curve correlating potential readings with known $\mathrm{Cl}^{-}$concentrations.

The method used to calculate the apparent diffusion coefficient $D$ of $\mathrm{Cl}^{-}$in cement mortars is described as follows: under an externally imposed electric field with an intensity of $E$, the mobility of ions ( $\nu$, the average velocity of ions per unit of electric field) is related to the diffusion coefficient through the Nernst-Einstein equation [31]:

$$
v=\frac{z F D}{R T},
$$

where $z$ is charge number, $F$ is Faraday constant, $R$ is gas constant, and $T$ is absolute temperature.

The chloride ion mobility can be calculated from the time $t_{0}$ required for the chloride front to penetrate a depth $d$ of the specimen [32]:

$$
\nu=\frac{d}{t_{0} E}
$$

Therefore, the diffusion coefficient $D$ of $\mathrm{Cl}^{-}$in cement mortars can be estimated using the following equation:

$$
D=\frac{d R T}{t_{0} E_{z} F}
$$

2.7. Morphological Study. The surface morphology of cement mortar samples, before and after EICI treatment, was studied using Field Emission Scanning Electron Microscopy (FESEM). The mortar surface was coated with a very thin carbon layer to avoid the charging effect caused by the nonconductive nature of epoxy coatings and to get high resolution material. The mortar surface morphology was evaluated using a FE-SEM S4800 (Hitachi, Japan) system, which offers an ultrahigh resolution at relatively low voltage.

\section{Results and Discussion}

3.1. $\left[\mathrm{TBA}^{+}\right]$Content by Time of EICI Treatment. Figures 5 and 6 present the UV-Vis spectra of cement mortar samples after EICI treatment in $0.1 \mathrm{M}$ sodium hydroxide and sodium borate solutions, respectively.

As can be seen in Figure 5, when using sodium hydroxide solution, the $\left[\mathrm{TBA}^{+}\right]$content in cement mortar (at distance of 


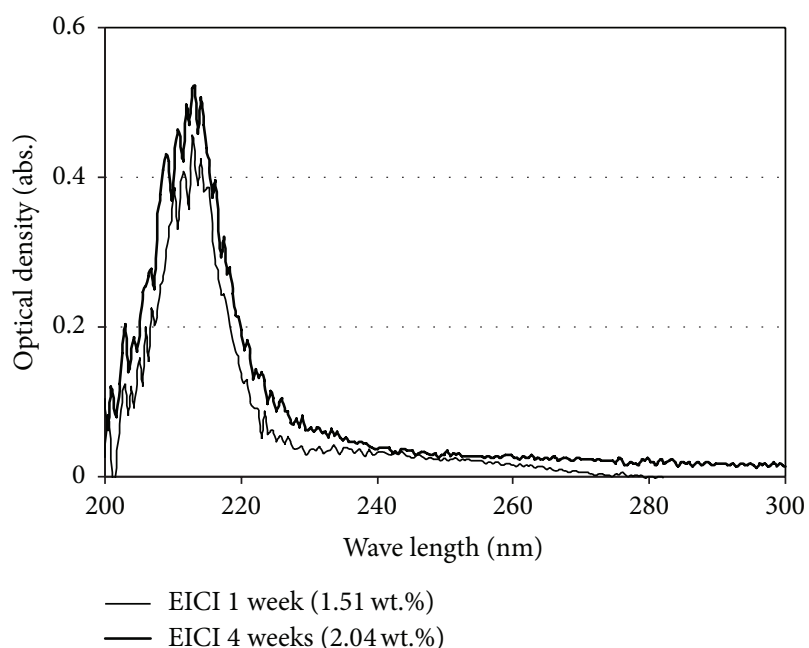

(a)

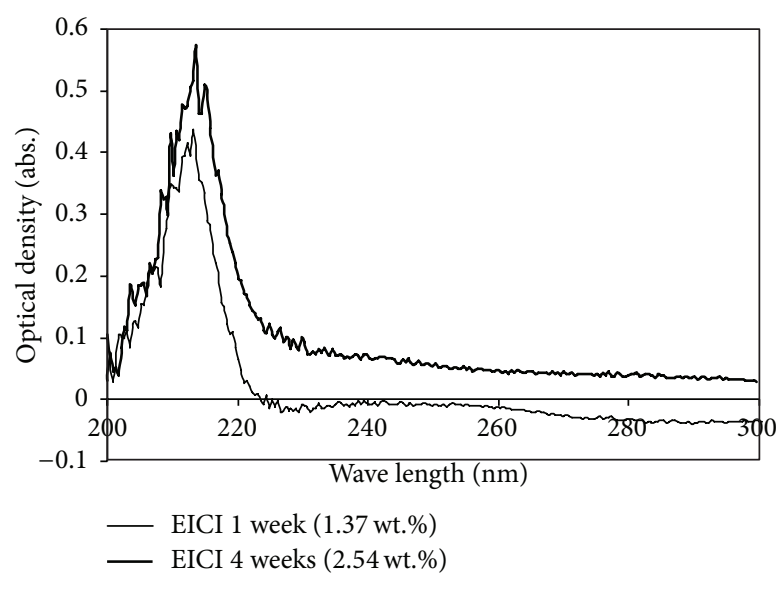

(b)

FIGURE 5: UV-Vis spectra of cement mortar samples after EICI treatment in sodium hydroxide solution: (a) uncontaminated sample; (b) contaminated sample.

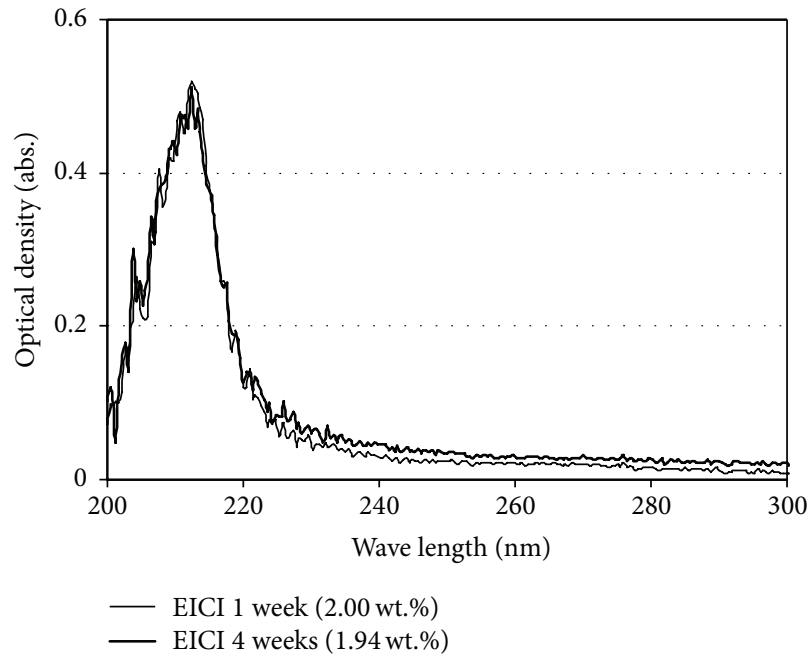

(a)

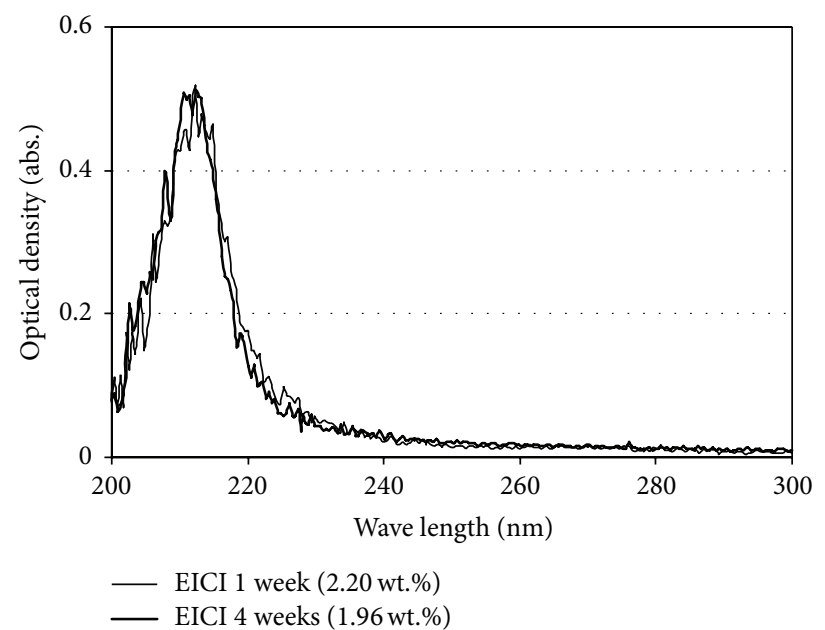

(b)

FIGURE 6: UV-Vis spectra of cement mortar samples after EICI treatment in sodium borate solution: (a) uncontaminated sample; (b) contaminated sample.

$10 \mathrm{~mm}$ from rebar) increased with the time of EICI treatment, for both uncontaminated and contaminated samples. For the contaminated mortar, after one week of treatment, $\left[\mathrm{TBA}^{+}\right]$ level was $1.37 \%$ by mass of cement mortar. This content reached $2.54 \%$ after four weeks of EICI treatment.

For samples treated in sodium borate electrolyte (Figure 6), similar results are obtained after one week of treatment. However, extending the time of treatment did not increase $\left[\mathrm{TBA}^{+}\right]$content for both contaminated and uncontaminated samples.

Data obtained from the UV-Vis spectra indicated that EICI-treated samples were found to contain the inhibitor concentration $\left[\mathrm{TBA}^{+}\right]$, as shown in Tables 1 and 2 , reported by weight of the mortar. As can be seen in Table 1, the increasing content of $\left[\mathrm{TBA}^{+}\right]$during the treatment in sodium hydroxide solution can be explained by the development of microcracks, as reported by Buenfeld and Broomfield [33]. The alkaline sodium borate electrolyte, acting as a buffer solution, may help to keep the mortar free from the development of microcracks due to the EICI treatment, whereas even though the $0.1 \mathrm{M} \mathrm{NaOH}$ solution had the higher $\mathrm{pH}$ value, the large amounts of hydroxide ions might be driven out of the mortar and into the electrolyte during the long EICI process. An acidic electrolyte might result in etching of the mortar surface and in the production of chlorine gas (for $\mathrm{Cl}^{-}$contaminated samples).

Data from Table 2 indicated that extending the time of treatment did not increase $\left[\mathrm{TBA}^{+}\right]$content. The higher 


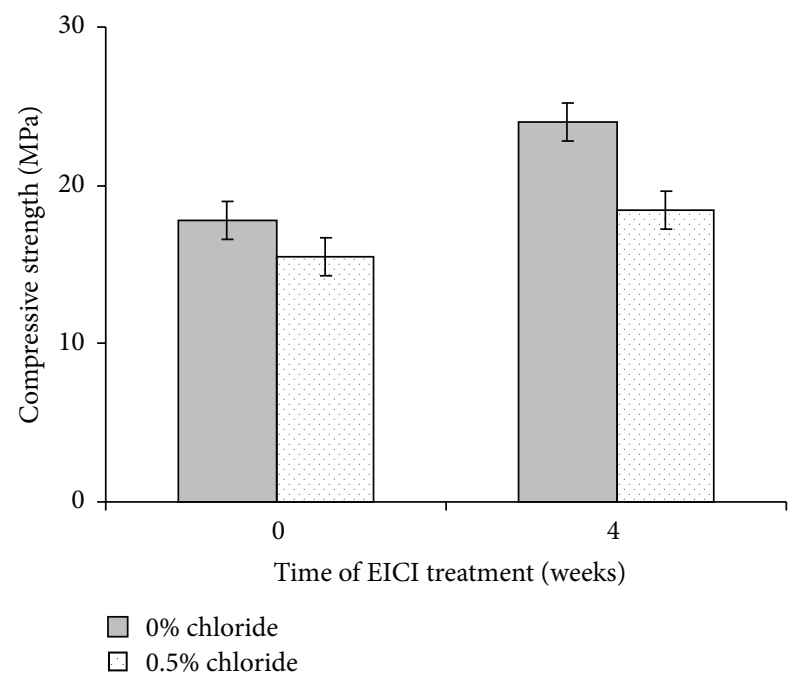

FIGURE 7: Compressive strength of cement mortar before and after EICI treatment in sodium hydroxide solution.

TABLE 1: $\left[\mathrm{TBA}^{+}\right]$content by time of EICI treatment in sodium hydroxide solution.

\begin{tabular}{lcc}
\hline \multirow{2}{*}{ Samples } & \multicolumn{2}{c}{$\left[\mathrm{TBA}^{+}\right]($wt. \%) } \\
& After 1 week of EICI test & After 4 weeks of EICI test \\
\hline $0 \%\left[\mathrm{Cl}^{-}\right]$ & $1.86 \pm 0.49$ & $2.26 \pm 0.30$ \\
$0.5 \%\left[\mathrm{Cl}^{-}\right]$ & $1.85 \pm 0.42$ & $2.40 \pm 0.21$ \\
\hline
\end{tabular}

TABLE 2: $\left[\mathrm{TBA}^{+}\right]$content by time of EICI treatment in sodium borate solution.

\begin{tabular}{lcc}
\hline \multirow{2}{*}{ Samples } & \multicolumn{2}{c}{$\left[\mathrm{TBA}^{+}\right]($wt. \%) } \\
& After 1 week of EICI test & After 4 weeks of EICI test \\
\hline $0 \%\left[\mathrm{Cl}^{-}\right]$ & $1.90 \pm 0.15$ & $2.05 \pm 0.15$ \\
$0.5 \%\left[\mathrm{Cl}^{-}\right]$ & $2.09 \pm 0.16$ & $1.94 \pm 0.04$ \\
\hline
\end{tabular}

mortar compressive strength after 4-week treatment in sodium borate electrolyte may be related to the physicochemical binding of $\left[\mathrm{TBA}^{+}\right]$with cement hydrates, which also decreased ionic permeability of the mortars. These two mechanisms help explain the lower $\left[\mathrm{TBA}^{+}\right]$content observed (Figures 7 and 8).

\subsection{Effect of EICI on the Compressive Strength of Mortars.} The strength of concrete originates from the strength of the hardened cement paste, which in turn originates from the hydration products. The major portion of the hydration products is in the form of a rigid gel (Calcium Silicate Hydrate (C-S-H) gel). It is believed that C-S-H gel is responsible for the strength and cohesion of concrete structures.

The results of compressive strength tests for the cement mortars before and after EICI treatment in sodium hydroxide and sodium borate solutions are shown in Figures 7 and 8 , respectively. As can be seen in these figures, the EICI treatment improved the compressive strength of the mortar.

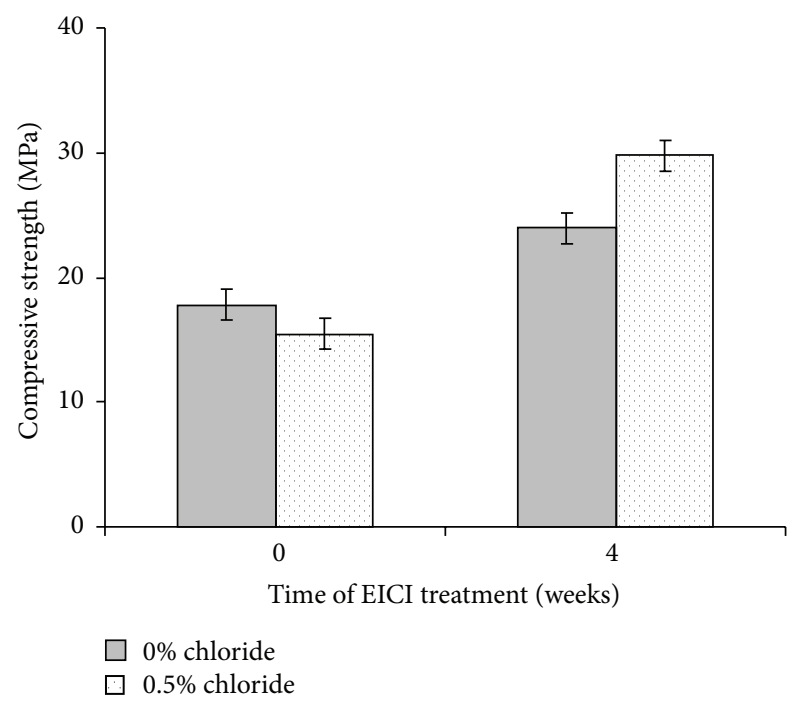

FIGURE 8: Compressive strength of cement mortar before and after EICI treatment in sodium borate solution.

As can be seen in Figures 7 and 8, the EICI treatment improved the compressive strength of the mortar. In comparison to the electrolyte solution, for contaminated samples, the compressive strengths obtained by treatment in sodium borate solution were higher than those from the sodium hydroxide solution (up to a $92 \%$ strength increase). Thus, the higher mortar strength after EICI test might be also attributable to the presence of inhibitor in the mortar.

Different from the $0.1 \mathrm{NaOH}$ solution, the $0.1 \mathrm{M} \mathrm{Na}_{3} \mathrm{BO}_{3}$ solution ( $\mathrm{pH}$ 9) is a $\mathrm{pH}$-buffered electrolyte, which could maintain alkalinity during the long time of EICI treatment, which prevents the electrolyte from becoming too acidic during the test. The observed strength changes may be attributed to the interactions of anions $\left(\mathrm{OH}^{-}\right.$or $\mathrm{BO}_{3}^{-}$versus $\left.\mathrm{Cl}^{-}\right)$ transported in the mortar (via diffusion or electromigration) with cement hydrates, which merits further investigation.

3.3. Effect of EICI on the Mortar Permeability. Figure 9 shows the chloride concentrations in the anolyte (destination solution) as a function of time during the electromigration test for mortars with or without EICI treatment. As can be seen in this figure, after EICI treatment in both of the $\mathrm{NaOH}$ and $\mathrm{Na}_{3} \mathrm{BO}_{3}$ solutions, the value of $t_{0}$ increased. The calculated $D_{\mathrm{CL}^{-}}$value thus was decreased by $38 \%$, from $1.0 \times$ $10^{-10} \mathrm{~m}^{2} / \mathrm{s}$ (without EICI treatment) to $6.2 \times 10^{-11} \mathrm{~m}^{2} / \mathrm{s}$ (after 4 weeks of EICI treatment in $\mathrm{NaOH}$ solution).

Regarding the $D_{\mathrm{CL}^{-}}$value for control sample (without EICI treatment), it is much higher than the value of $7.3 \times$ $10^{-11} \mathrm{~m}^{2} / \mathrm{s}$, reported by Nguyen et al. [34], which was obtained for the mortars as-prepared without rebar inside. In this study, mortar discs (with rebar inside) were sliced into $\sim 20 \mathrm{~mm}$ width slice, along the $100 \mathrm{~mm}$ length of the steel reinforced mortar. Therefore, the method preparing mortar discs for electromigration test might produce microcracks inside the discs. 


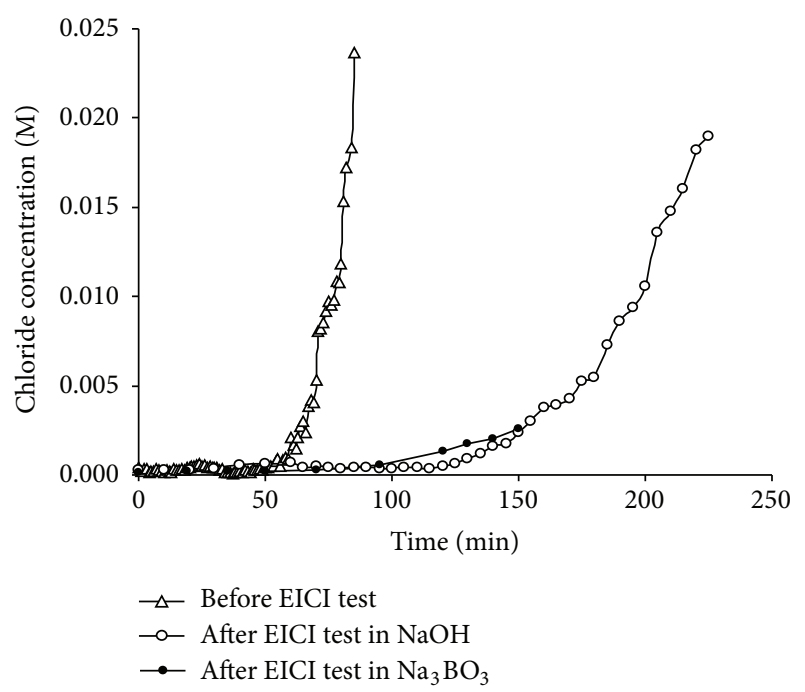

FIGURE 9: Evolution of chloride concentration in anolyte over time of electromigration test for mortar discs (with and without EICI treatment).

Transport of ionic and molecular species in mortar is mainly through the pore solution. Thus, by EICI treatment, $\left[\mathrm{TBA}^{+}\right]$cations may chemically and physically react with cement hydrates and lead to a less permeable microstructure of cement mortars.

The FESEM test revealed that the $\left[\mathrm{TBA}^{+}\right]$not only led to denser cement mortar but also changed the morphology of cement hydration products. Figures 10 (a)-10(d) show the FESEM images of cement mortars before and after EICI treatment. As shown in Figures 10(c) and 10(d), after EICI treatment, the cement mortars featured denser and more compact microstructure, which is likely attributed to the chemical and physical binding of $\left[\mathrm{TBA}^{+}\right]$to the $\mathrm{C}-\mathrm{S}-\mathrm{H}$ gel and other cement hydrates. These physicochemical changes in the mortars after the EICI treatment are likely responsible for the observed increases in their compressive strength (as seen in Figure 7).

3.4. Effect of EICI on Corrosion State of Steel Rebar. Tables 3 and 4 present the corrosion potential $\left(E_{\text {corr }}\right)$, polarization resistance $\left(R_{p}\right)$, and corrosion current $\left(i_{\text {corr }}\right)$ values deduced from the weak polarization tests for samples with or without EICI treatment in sodium hydroxide solution, for uncontaminated and contaminated samples, respectively. As can be seen in these tables, the presence of chloride in cement mortar increased significantly the corrosion current of rebar (up to 8.6 times current increase). Tables 5 and 6 present also the corrosion potential $\left(E_{\text {corr }}\right)$, polarization resistance $\left(R_{p}\right)$, and corrosion current $\left(i_{\text {corr }}\right)$ values deduced from the weak polarization tests for samples with or without EICI treatment in sodium borate solution, for uncontaminated and contaminated samples, respectively. It can be observed from these tables that, after EICI treatment, the corrosion potentials of all samples were more positive and it was possible to passivate the steel.
TABLE 3: $E_{\text {corr }}, R_{p}$, and $i_{\text {corr }}$ values obtained from the weak polarization tests for uncontaminated samples with or without EICI treatment in sodium hydroxide solution.

\begin{tabular}{lcccc}
\hline $\begin{array}{l}\text { Time of EICI } \\
\text { treatment } \\
\text { (weeks) }\end{array}$ & $\begin{array}{c}E_{\text {corr }} \\
(\mathrm{V} / \mathrm{SCE})\end{array}$ & $\begin{array}{c}R_{p} \\
\left(\Omega \cdot \mathrm{cm}^{2}\right)\end{array}$ & $\begin{array}{c}i_{\text {corr }} \\
\left(\mathrm{mA} / \mathrm{cm}^{2}\right)\end{array}$ & $\begin{array}{c}\text { Inhibition } \\
\text { efficiency } \\
(\%)\end{array}$ \\
\hline 0 & -0.286 & $2.25 E+05$ & $1.16 E-04$ & $\mathrm{~N} / \mathrm{A}$ \\
2 & -0.223 & $1.87 E+05$ & $1.39 E-04$ & -19.8 \\
4 & -0.164 & $2.46 E+05$ & $1.06 E-04$ & 8.6 \\
\hline
\end{tabular}

TABLE 4: $E_{\text {corr }}, R_{p}$, and $i_{\text {corr }}$ values obtained from the weak polarization tests for contaminated samples $(0.5 \%$ chloride) with or without EICI treatment in sodium hydroxide solution.

\begin{tabular}{lcccc}
\hline $\begin{array}{l}\text { Time of EICI } \\
\text { treatment } \\
\text { (weeks) }\end{array}$ & $\begin{array}{c}E_{\text {corr }} \\
(\mathrm{V} / \mathrm{SCE})\end{array}$ & $\begin{array}{c}R_{p} \\
\left(\Omega \cdot \mathrm{cm}^{2}\right)\end{array}$ & $\begin{array}{c}i_{\text {corr }} \\
\left(\mathrm{mA} / \mathrm{cm}^{2}\right)\end{array}$ & $\begin{array}{c}\text { Inhibition } \\
\text { efficiency } \\
(\%)\end{array}$ \\
\hline 0 & -0.356 & $2.610 E+04$ & $9.96 E-04$ & N/A \\
2 & -0.016 & $2.36 E+05$ & $2.20 E-04$ & 77.9 \\
4 & -0.029 & $1.94 E+05$ & $2.68 E-04$ & 73.5 \\
\hline
\end{tabular}

TABLE 5: $E_{\text {corr }}, R_{p}$, and $I_{\text {corr }}$ values obtained from the weak polarization tests for uncontaminated samples with or without EICI treatment in sodium borate solution.

\begin{tabular}{lcccc}
\hline $\begin{array}{l}\text { Time of EICI } \\
\text { treatment } \\
\text { (weeks) }\end{array}$ & $\begin{array}{c}E_{\text {corr }} \\
(\mathrm{V} / \mathrm{SCE})\end{array}$ & $\begin{array}{c}R_{p} \\
\left(\Omega \cdot \mathrm{cm}^{2}\right)\end{array}$ & $\begin{array}{c}i_{\text {corr }} \\
\left(\mathrm{mA} / \mathrm{cm}^{2}\right)\end{array}$ & $\begin{array}{c}\text { Inhibition } \\
\text { efficiency } \\
(\%)\end{array}$ \\
\hline 0 & -0.286 & $2.25 E+05$ & $1.16 E-04$ & $\mathrm{~N} / \mathrm{A}$ \\
2 & -0.079 & $2.42 E+05$ & $2.14 E-04$ & -84.5 \\
4 & -0.138 & $4.53 E+05$ & $5.74 E-05$ & 50.9 \\
\hline
\end{tabular}

TABLE 6: $E_{\text {corr }}, R_{p}$, and $I_{\text {corr }}$ values obtained from the weak polarization tests for contaminated samples $(0.5 \%$ chloride $)$ with or without EICI treatment in sodium borate solution.

\begin{tabular}{lcccc}
\hline $\begin{array}{l}\text { Time of EICI } \\
\text { treatment } \\
\text { (weeks) }\end{array}$ & $\begin{array}{c}E_{\text {corr }} \\
(\mathrm{V} / \mathrm{SCE})\end{array}$ & $\begin{array}{c}R_{p} \\
\left(\Omega \cdot \mathrm{cm}^{2}\right)\end{array}$ & $\begin{array}{c}i_{\text {corr }} \\
\left(\mathrm{mA} / \mathrm{cm}^{2}\right)\end{array}$ & $\begin{array}{c}\text { Inhibition } \\
\text { efficiency } \\
(\%)\end{array}$ \\
\hline 0 & -0.356 & $2.610 E+04$ & $9.96 E-04$ & N/A \\
2 & -0.066 & $2.43 E+05$ & $2.14 E-04$ & 78.5 \\
4 & -0.055 & $9.15 E+04$ & $5.68 E-04$ & 43.0 \\
\hline
\end{tabular}

Figures 11 and 12 summarize the polarization resistance values of steel rebar embedded in chloride-contaminated cement mortar before and after EICI treatment in sodium hydroxide and sodium borate solutions, respectively. Regarding the $R_{p}$ values, except the uncontaminated samples after EICI treatment in sodium hydroxide solution, $R_{p}$ increased after EICI treatment. The higher increase was obtained with contaminated samples; thus the EICI treatment was more effective for chloride-contaminated mortar. Regarding the $i_{\text {corr }}$ values shown in Tables 3-6, for chloride-contaminated cement mortars, after 2 weeks of EICI treatment by both of the electrolytes, $i_{\text {corr }}$ decreased by about $78 \%$. However, for uncontaminated cement mortars, after 2 weeks of EICI treatment, $i_{\text {corr }}$ increased. Kubo et al. [21] also reported 


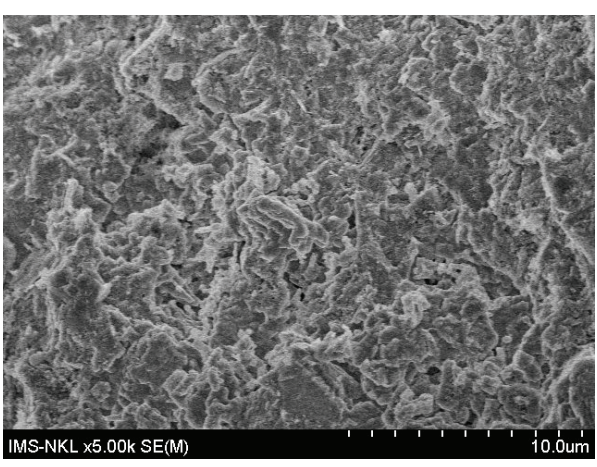

(a)

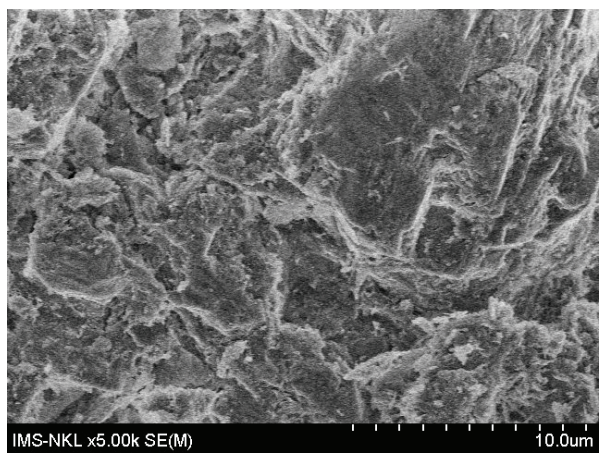

(c)

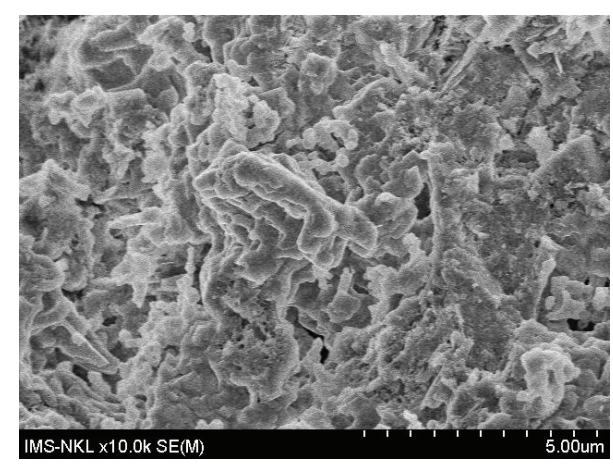

(b)

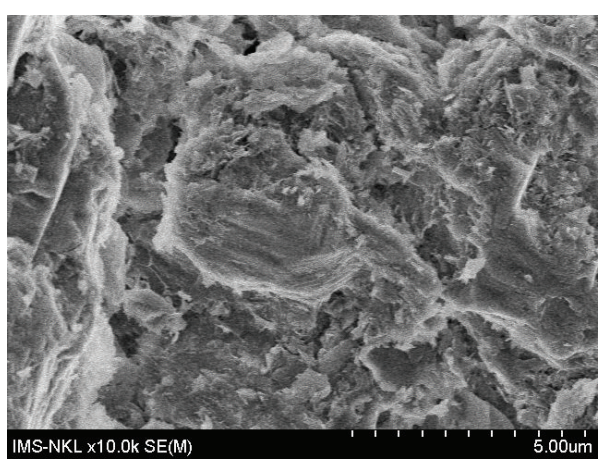

(d)

FIGURE 10: FESEM images of cement mortars: ((a) and (b)) before EICI treatment; ((c) and (d)) after 4 weeks of EICI treatment. Magnification for (a) to (d): at 5000x (on the left) and at 10000x (on the right), for each sample, to illustrate typical microstructure.

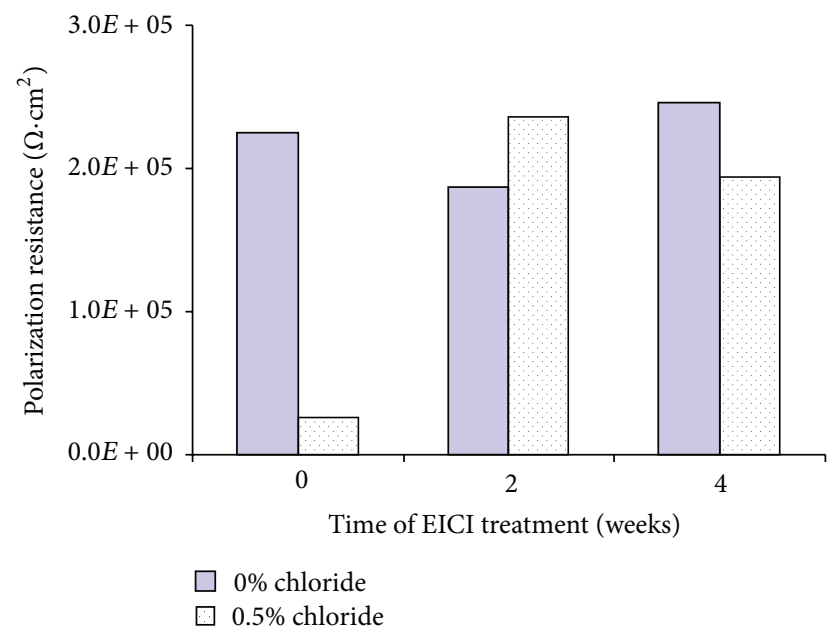

FIGURE 11: Polarization resistance values for steel rebar embedded in chloride-contaminated cement mortar before and after EICI treatment in sodium hydroxide solution.

an increase of $i_{\text {corr }}$ after EICI for the real carbonated reinforced concrete located in Tokyo city. In their work, the EICI treatment was carried out during 1 week at a constant current density of $5 \mathrm{~A} / \mathrm{m}^{2}$ using the ethanolamine solution. After EICI test, $i_{\text {corr }}$ increased by $88.9 \%$ from the value of $9 E$ $05 \mathrm{~mA} / \mathrm{cm}^{2}$ (before EICI test). In these cases, the short time

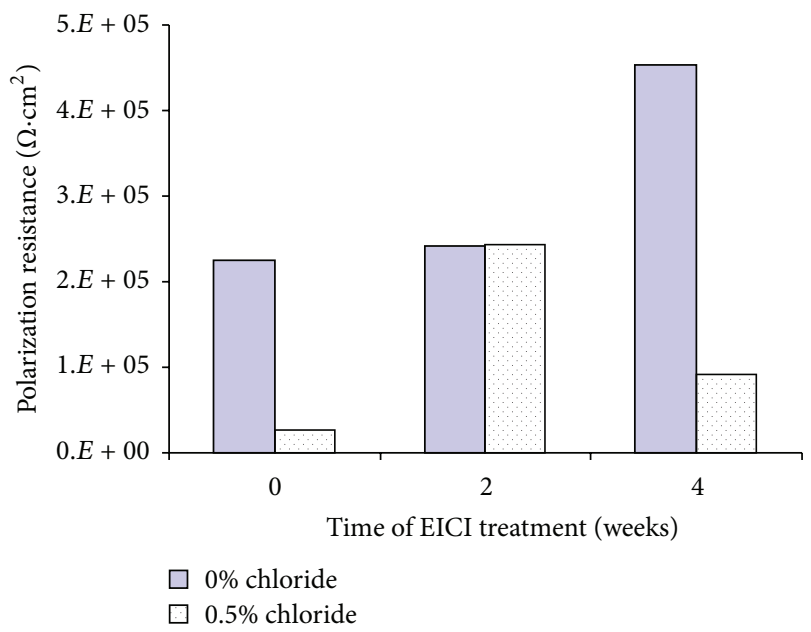

FIGURE 12: Polarization resistance values of steel rebar embedded in chloride-contaminated cement mortar before and after EICI treatment in sodium borate solution.

EICI treatment (1-2 weeks) might harm the uncontaminated reinforced mortar. This is likely attributed to the alternation of concrete microstructure and composition of mortar pore solution by the externally applied electric field. On the other hand, for contaminated samples treated by $\mathrm{NaOH}$ and $\mathrm{Na}_{3} \mathrm{BO}_{3}$ solutions, the inhibition efficiencies after EICI treatment for 4 weeks are $73.5 \%$ and $43 \%$, lower than those 
after treatment for 2 weeks, $77.9 \%$ and $78.5 \%$, respectively. Thus, the long time EICI treatment (4 weeks) might harm the contaminated reinforced mortar.

\section{Conclusions}

The main findings of this investigation include the following:

(i) EICI treatment was more effective in injecting organic inhibitor when using sodium hydroxide solution as electrolyte. In this case, after 4-week EICI treatment, $\left[\mathrm{TBA}^{+}\right]$content was $2.0 \%$ and $2.5 \%$ by mass of cement mortar, for uncontaminated and chloridecontaminated samples, respectively.

(ii) The potentiodynamic weak polarization tests showed that EICI treatment halted chloride-induced corrosion of the rebar. After 2 weeks of EICI treatment using $0.1 \mathrm{M} \mathrm{NaOH}$ and $0.1 \mathrm{M} \mathrm{Na} \mathrm{NO}_{3}$ solutions, the values of $i_{\text {corr }}$ decreased by $77.8 \%$ and $78.5 \%$, respectively.

(iii) The electromigration test showed that EICI treatment improved the chloride penetration resistance of the mortar, as indicated by the reduced apparent diffusion coefficients of chloride anion, $D_{\mathrm{Cl}^{-}}$. The calculated $D_{\mathrm{Cl}^{-}}$values thus were decreased by $38 \%$ from $1.0 \times 10^{-10} \mathrm{~m}^{2} / \mathrm{s}$. The FESEM test revealed that the $\left[\mathrm{TBA}^{+}\right]$not only led to denser cement mortar but also changed the morphology of cement hydration products.

(iv) Under the investigated conditions, the EICI treatment significantly improved the compressive strength of cement mortars. This benefit was greater when using sodium borate solution (up to $92 \%$ strength increase).

\section{Conflict of Interests}

The authors declare that there is no conflict of interests regarding the publication of this paper.

\section{Acknowledgment}

This work was financially supported by the Vietnam Ministry of Science and Technology (project under protocol of Vietnam-USA, Grant no. 47/2012/HD-NDT).

\section{References}

[1] S. Ahmad, "Reinforcement corrosion in concrete structures, its monitoring and service life prediction-a review," Cement and Concrete Composites, vol. 25, no. 4-5, pp. 459-471, 2003.

[2] X. Shi, L. Fay, K. Fortune et al., "Longevity of corrosion inhibitors and performance of liquid deicer products under field storage," Canadian Journal of Civil Engineering, vol. 39, no. 2, pp. 117-127, 2012.

[3] X. Shi, Y. Liu, M. Mooney, M. Berry, B. Hubbard, and T. A. Nguyen, "Laboratory investigation and neural networks modeling of deicer ingress into Portland cement concrete and its corrosion implications," Corrosion Reviews, vol. 28, no. 3-4, pp. 105-154, 2010.
[4] X. Shi, T. A. Nguyen, P. Kumar, and Y. Liu, "A phenomenological model for the chloride threshold of pitting corrosion of steel in simulated concrete pore solutions," Anti-Corrosion Methods and Materials, vol. 58, no. 4, pp. 179-189, 2011.

[5] H. Yu, X. Shi, W. H. Hartt, and B. Lu, "Laboratory investigation of reinforcement corrosion initiation and chloride threshold content for self-compacting concrete," Cement and Concrete Research, vol. 40, no. 10, pp. 1507-1516, 2010.

[6] G. R. Meira, C. Andrade, E. O. Vilar, and K. D. Nery, "Analysis of chloride threshold from laboratory and field experiments in marine atmosphere zone," Construction and Building Materials, vol. 55, pp. 289-298, 2014.

[7] C. L. Page, N. R. Short, and W. R. Holden, "The influence of different cements on chloride-induced corrosion of reinforcing steel," Cement and Concrete Research, vol. 16, no. 1, pp. 79-86, 1986.

[8] G. K. Glass and N. R. Buenfeld, "Chloride-induced corrosion of steel in concrete," Progress in Structural Engineering and Materials, vol. 2, no. 4, pp. 448-458, 2000.

[9] G. Batis, A. Routoulas, and E. Rakanta, "Effects of migrating inhibitors on corrosion of reinforcing steel covered with repair mortar," Cement and Concrete Composites, vol. 25, no. 1, pp. 109115, 2003.

[10] X. Shi, Z. Yang, T. A. Nguyen, Z. Suo, R. Avci, and S. Song, "An electrochemical and microstructural characterization of steelmortar admixed with corrosion inhibitors," Science in China Series E: Technological Sciences, vol. 52, no. 1, pp. 52-66, 2009.

[11] P. Faustino, A. Brás, and T. Ripper, "Corrosion inhibitors' effect on design service life of RC structures," Construction and Building Materials, vol. 53, pp. 360-369, 2014.

[12] B. Elsener, "Corrosion of reinforcement in concrete: mechanisms, monitoring, inhibitors and rehabilitation techniques," EFC 38, Woodhead Publishing, Cambridge, UK, 2001.

[13] S. L. Matthews and J. R. Morlidge, "Performance based rehabilitation of reinforced concrete structures," in Concrete Repair, Rehabilitation and Retrofitting II, M. G. Alexander, H.-D. Beushausen, F. Dehn, and P. Moyo, Eds., Taylor \& Francis, London, UK, 2009.

[14] B. Elsener and R. Cigna, "Surface applied inhibitors," in COST 521: Corrosion of Steel in Reinforced Concrete Structures, R. Wydert, Ed., European Cooperation in Science and Technology, Luxembourg City, Luxemburg, 2002.

[15] C. L. Page, V. T. Ngala, and M. M. Page, "Corrosion inhibitors in concrete repair systems," Magazine of Concrete Research, vol. 52, no. 1, pp. 25-37, 2000.

[16] T. A. Söylev and M. G. Richardson, "Corrosion inhibitors for steel in concrete: state-of-the-art report," Construction and Building Materials, vol. 22, no. 4, pp. 609-622, 2008.

[17] S. Sawada, C. L. Page, and M. M. Page, "Electrochemical injection of organic corrosion inhibitors into concrete," Corrosion Science, vol. 47, no. 8, pp. 2063-2078, 2005.

[18] T. Pan, T. A. Nguyen, and X. Shi, "Assessment of electrical injection of corrosion inhibitor for corrosion protection of reinforced concrete," Transportation Research Record, vol. 2044, pp. 51-60, 2008.

[19] Y. Liu and X. Shi, "Electrochemical chloride extraction and electrochemical injection of corrosion inhibitor in concrete: state of the knowledge," Corrosion Reviews, vol. 27, no. 1-2, pp. 53-82, 2009.

[20] M. Sánchez and M. C. Alonso, "Electrochemical chloride removal in reinforced concrete structures: improvement of 
effectiveness by simultaneous migration of calcium nitrite," Construction and Building Materials, vol. 25, no. 2, pp. 873-878, 2011.

[21] J. Kubo, Y. Tanaka, C. L. Page, and M. M. Page, "Application of electrochemical organic corrosion inhibitor injection to a carbonated reinforced concrete railway viaduct," Construction and Building Materials, vol. 39, pp. 2-8, 2013.

[22] S. Sawada, J. Kubo, C. L. Page, and M. M. Page, "Electrochemical injection of organic corrosion inhibitors into carbonated cementitious materials: part 1. Effects on pore solution chemistry," Corrosion Science, vol. 49, no. 3, pp. 1186-1204, 2007.

[23] J. Kubo, S. Sawada, C. L. Page, and M. M. Page, "Electrochemical inhibitor injection for control of reinforcement corrosion in carbonated concrete," Materials and Corrosion, vol. 59, no. 2, pp. 107-114, 2008.

[24] M. Ormellese, M. Berra, F. Bolzoni, and T. Pastore, "Corrosion inhibitors for chlorides induced corrosion in reinforced concrete structures," Cement and Concrete Research, vol. 36, no. 3, pp. 536-547, 2006.

[25] Y. Li, Y. Zhang, S. Jungwirth, N. Seely, Y. Fang, and X. Shi, "Corrosion inhibitors for metals in maintenance equipment: introduction and recent developments," Corrosion Reviews, vol. 32, no. 5-6, pp. 163-181, 2014.

[26] L. Schueremans, Ö. Cizer, E. Janssens, G. Serré, and K. Van Balen, "Characterization of repair mortars for the assessment of their compatibility in restoration projects: research and practice," Construction and Building Materials, vol. 25, no. 12, pp. 4338-4350, 2011.

[27] S. Jorge, D. Dias-da-Costa, and E. N. B. S. Júlio, "Influence of anti-corrosive coatings on the bond of steel rebars to repair mortars," Engineering Structures, vol. 36, pp. 372-378, 2012.

[28] A. Matsui, "The introduction of cement and concrete technology in Vietnam and Japan, Japan Society of Civil Engineers," in Proceedings of the JSCE-VIFCEA Joint Seminar on Concrete Engineering in Vietnam and Workshop, Newsletter No. 5, pp. 132-139, April 2006.

[29] G. E. Bennett and K. P. Johnston, "UV-visible absorbance spectroscopy of organic probes in supercritical water," Journal of Physical Chemistry, vol. 98, no. 2, pp. 441-447, 1994.

[30] X. Shi, N. Xie, K. Fortune, and J. Gong, "Durability of steel reinforced concrete in chloride environments: an overview," Construction and Building Materials, vol. 30, pp. 125-138, 2012.

[31] P. W. Atkins, Physical Chemistry, Oxford University Press, Oxford, UK, 5th edition, 1994.

[32] W. B. Russel, D. A. Saville, and W. R. Schowalter, Colloidal Dispersions, Cambridge University Press, Cambridge, UK, 1989.

[33] N. R. Buenfeld and J. P. Broomfield, "Effect of chloride removal on rebar bond strength and concrete properties," in Proceedings of the Conference on Corrosion and Corrosion Protection of Steel in Concrete, R. N. Swamy, Ed., vol. 2, pp. 1438-1450, Sheffield Academic Press, Sheffield, UK, 1994.

[34] T. A. Nguyen, T. H. Nguyen, T. L. Pham, T. M. T. Dinh, H. Thai, and X. Shi, "Application of nano- $\mathrm{SiO}_{2}$ and nano- $-\mathrm{Fe}_{2} \mathrm{O}_{3}$ for protection of steel rebar in chloride contaminated concrete: epoxy nanocomposite coatings and nano-modified mortars," Journal of Nanoscience and Nanotechnology, In press. 

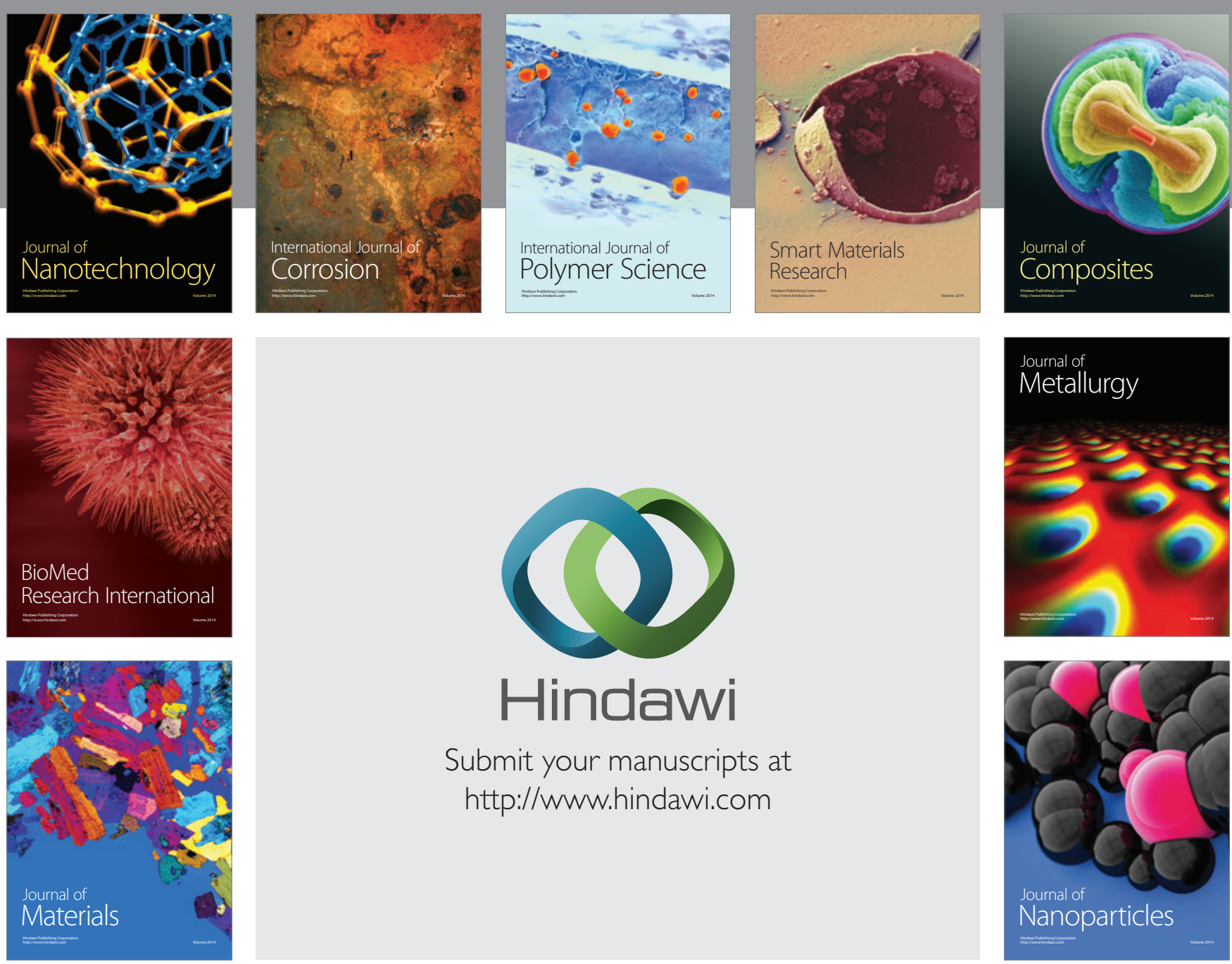

Submit your manuscripts at http://www.hindawi.com
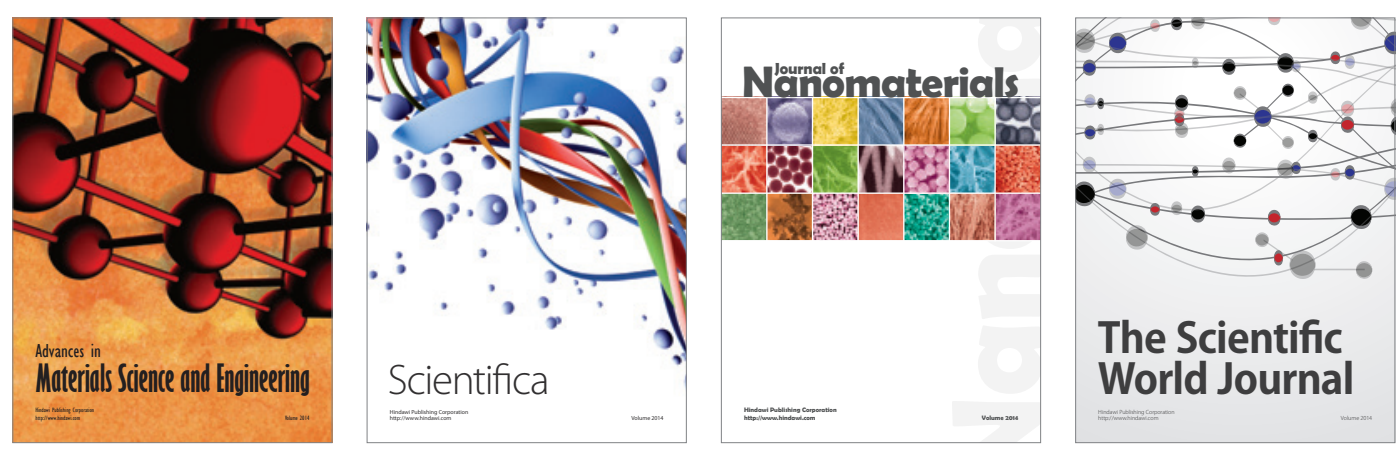

\section{The Scientific World Journal}
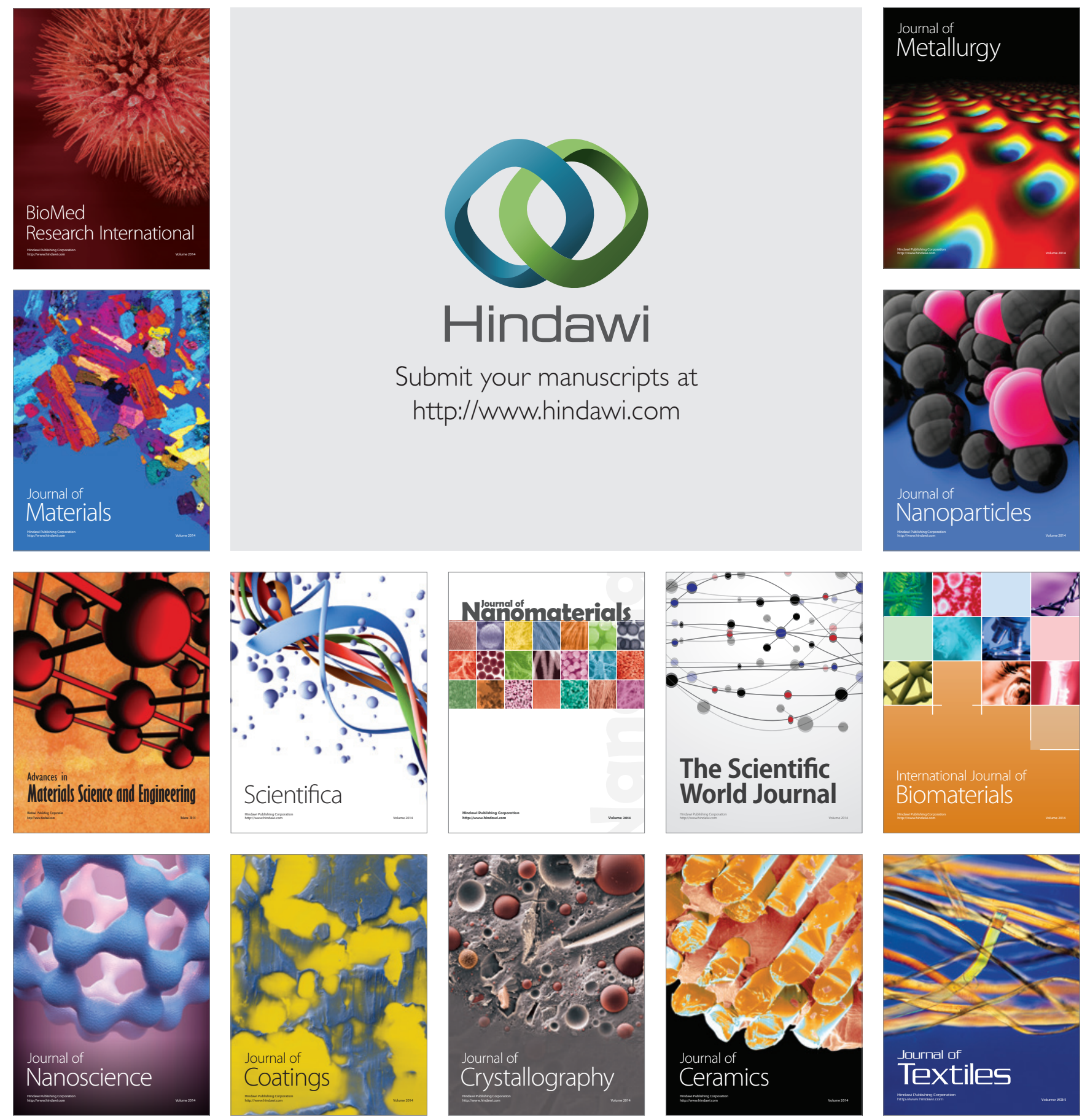